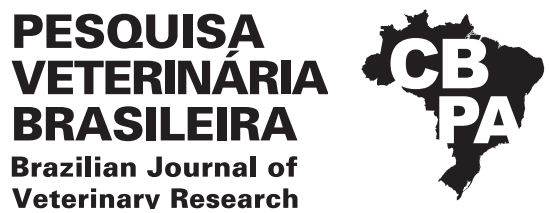

Pesq. Vet. Bras. 42:e06819, 2022

DOI: 10.1590/1678-5150-PVB-6819

Original Article

Livestock Diseases

ISSN 0100-736X (Print)

ISSN 1678-5150 (Online)

\title{
Equine abortion associated with placentitis caused by Pasteurella pneumotropica ${ }^{1}$
}

\author{
Gregory D. Juffo ${ }^{2}$ (D) Nadia A.B. Antoniassi ${ }^{3}$ (D) Daniele M. Bassuino ${ }^{2}$ (D), \\ Danilo C. Gomes ${ }^{4}$ (D), Gustavo G.M. Snel ${ }^{2}$, Saulo P. Pavarini ${ }^{2}$ (D) \\ and David Driemeier ${ }^{2 *}$ (D)
}

\begin{abstract}
Juffo G.D., Antoniassi N.A.B., Bassuino D.M., Gomes D.C., Snel G.G.M., Pavarini S.P. \& Driemeier D. 2022. Equine abortion associated with placentitis caused by Pasteurella pneumotropica. Pesquisa Veterinária Brasileira 42:e06819, 2022. Setor de Patologia Veterinária, Departamento de Patologia Clínica Veterinária, Faculdade de Veterinária, Universidade Federal do Rio Grande do Sul, Av. Bento Gonçalves 9090, Prédio 42505, Porto Alegre, RS 91540-000, Brazil. E-mail: davetpat@ufrgs.br

Pasteurella pneumotropica is a bacterium that has so far not been described as a cause of placentitis in animals. Two cases of aborted equine fetuses were sent to the Department of Veterinary Pathology of the "Universidade Federal do Rio Grande do Sul" (SPV-UFRGS) for anatomopathological examination. Both cases presented suppurative placentitis associated with multiple basophilic bacterial cells. After bacterial isolation and biochemical analysis, P. pneumotropica was identified.
\end{abstract}

INDEX TERMS: Abortion, equine, placentitis, pregnancy loss, pasteurelosis, Pasteurella pneumotropica.

\begin{abstract}
RESUMO.- [Aborto equino associado a placentite por Pasteurella pneumotropica.] Pasteurella pneumotropica é uma bactéria que até o momento não foi descrita como causa de placentite em animais. Dois casos de fetos equinos abortados foram enviados ao Setor de Patologia Veterinária da Universidade Federal do Rio Grande do Sul (SPV-UFRGS) para exame anatomopatológico. Em ambos os casos se observou placentite supurativa associada a múltiplas colônias bacterianas basofílicas. Após o isolamento bacteriano e análise bioquímica, indentificou-se P. pneumotropica.
\end{abstract}

TERMOS DE INDEXAÇÃO: Aborto, equino, placentite, perda gestacional, pasteurelose, Pasteurella pneumotropica.

\footnotetext{
${ }^{1}$ Received on July 20, 2021.

Accepted for publication on August 24, 2021.

${ }^{2}$ Setor de Patologia Veterinária (SPV), Departamento de Patologia Clínica Veterinária, Faculdade de Medicina Veterinária, Universidade Federal do Rio Grande do Sul (UFRGS), Av. Bento Gonçalves 9090, Porto Alegre, RS 91540000, Brazil. *Corresponding author: davetpat@ufrgs.br

${ }^{3}$ Laboratório de Patologia Animal, Instituto de Ciências da Saúde, Universidade Federal de Mato Grosso (UFMT), Av. Alexandre Ferronato 1200, Setor Industrial, Sinop, MT 78550-728, Brazil.

${ }^{4}$ Laboratório de Anatomia Patológica, Faculdade de Medicina Veterinária e Zootecnia, Universidade Federal de Mato Grosso do Sul (UFMS), Av. Senador Felinto Muller 2443, Campo Grande, MS 79074-460, Brazil.
}

\section{INTRODUCTION}

Members of the Pasteurellaceae family are Gram-negative, immobile, coccoid, facultative anaerobic bacteria that produce acids from carbohydrates (Mannheim 1984). They are opportunistic pathogens, typically commensal, inhabiting mucous membranes of the respiratory and genital tracts and capable of causing primary and secondary infections (Schlater et al. 1989, Ward et al. 1998).

In equine species, bacteria of the genus Pasteurella are rarely associated with disease and death (Schlater 1989). In humans, Pasteurella pneumotropica (also known as Rodentibacter pneumotropicus) occasionally acts as an opportunistic agent (Minton 1990, Nimri et al. 2001). In England, this bacterium was the second most frequently isolated from the lower respiratory tract in horses (Ward et al. 1998). Sporadic cases of neonatal septicemia, pneumonia, abortions, and ulcerative lymphangitis caused by Mannheimia haemolytica in horses have been described (Saxegaard \& Svenkerud 1974, Webb et al. 1980, Miller \& Dresher 1981). However, to date, there have been no reports of reproductive problems associated with P. pneumotropica infections in horses. The objective of this study was to describe anatomopathological lesions in the placenta and in two equine fetuses aborted due to $P$. pneumotropica infection. 


\section{MATERIALS AND METHODS}

Two equine fetuses and fetal membranes were sent to the "Setor de Patologia Veterinária" (Veterinary Pathology Department) of the "Universidade Federal do Rio Grande do Sul" (SPV-UFRGS) for anatomopathological examination. Data on the origin of the mares and history of the farms where the cases occurred were provided by the owners and responsible veterinarians. Fetuses and placentas were macroscopically analyzed by necropsy examination. Tissue fragments were collected and fixed in $10 \%$ buffered formalin, routinely processed for histopathology, and stained with hematoxylin and eosin (HE). Lung, liver, stomach content, and placenta samples were aseptically collected, refrigerated, and sent for bacterial culture to the UFRGS Laboratory of Veterinary Bacteriology. The tissues were inoculated in 5\% sheep blood agar and MacConkey agar medium and incubated under aerobic and capnophilic conditions for $48 \mathrm{~h}$ at $37^{\circ} \mathrm{C}$. Additionally, biochemical tests, including profiling with the API 20E system (BioMerieux), were performed. Placenta and liver samples were also sent to the UFRGS Laboratory of Mycology for mycological culture. Direct immunofluorescence (DIF) testing for Leptospira spp. was performed using kidney imprints with a commercial multivalent antibody at a dilution of 1:20 (Miller et al. 1989). Immunohistochemistry (IHC) for equine herpesvirus type 1 with an HVE-1 monoclonal antibody (WMRD Pullman) at a dilution of 1:100 in phosphate-buffered saline (PBS) was performed using lung and liver paraffin blocks. Antigenic recovery was performed with $0.05 \%$ protease XVI for $15 \mathrm{~min}$ at $37^{\circ} \mathrm{C}$. The primary antibody was applied for $45 \mathrm{~min}$ at $37^{\circ} \mathrm{C}$, followed by the biotinylated secondary antibody and streptavidin solution conjugated to a molecule of alkaline phosphatase (LSAB + System AP, Dako Cytomation) for approximately $20 \mathrm{~min}$ each at room temperature. Permanent Red (Permanent Red/code 0695, Dako) was used as the chromogen. Positive controls were inserted simultaneously with the slides tested.

\section{RESULTS}

According to the owners and veterinarians, the fetuses corresponded to the gestational ages of four (Fetus 1) and six months (Fetus 2). Both mares were American Quarter Horses and were 19 and 17 years old, respectively. Neither presented clinical signs before or after abortion. The cases were from two different stud farms located in the state of Rio Grande do Sul.

Macroscopically, Fetus 1 measured $29 \mathrm{~cm}$ in length (from the nape of the neck to the insertion of the tail), a size compatible with the gestational age reported by the owner (Ginther 1992, Franciolli et al. 2011). Externally, anasarca and petechiae were distributed throughout the skin. Placental blood vessels were markedly hyperemic (Fig.1). Fetus 2 was within the fetal membranes, which contained brownish and viscous amniotic fluid. The fetus measured $65 \mathrm{~cm}$ in length, which was also compatible with the reported gestational age (Ginther 1992, Franciolli et al. 2011). Multiple irregularly contoured and slightly elevated white plaques were randomly distributed over the skin of the head (Fig.2), trunk (mainly on the dorsal region), and limbs. There was moderate whitish mucous secretion in the nostrils. The thymus and lung presented multiple ecchymoses. The placenta was diffuse and moderately thickened, reddish, and with hyperemic blood vessels (Fig.3).

Histopathological examination of both placentas showed chorionic villi with moderate neutrophilic inflammatory infiltrate associated with multiple basophilic coccoid bacterial myriads diffusely distributed throughout the mucosal layer (Fig.4). Fetus 1 did not present significant changes. In Fetus 2 , the white plaques observed in the skin were characterized by moderate multifocal areas of orthokeratotic hyperkeratosis associated with mild neutrophilic inflammatory infiltrate. The liver and thymus presented marked foci of hemorrhage. The lung was diffusely and moderately congested, with small, amorphous, and homogeneous eosinophilic aggregates (keratin) in the alveolar lumen.

Bacteriological examination of the lung and stomach content from Fetus 1 and the placenta from Fetus 2 showed the growth of small pure grayish-white, mucoid, non-hemolytic colonies on blood agar. There was no growth on MacConkey agar. Catalase- and oxidase-positive gram-negative coccobacilli, characteristic of the genus Pasteurella, were isolated. The API 20 E system and other biochemical tests confirmed Pasteurella pneumotropica isolation. DIF tests for Leptospira spp., IHC tests for EHV-1, and mycological cultures were negative.

\section{DISCUSSION}

The diagnosis of equine abortion associated with placentitis caused by Pasteurella pneumotropica was established based on macroscopic and histological changes observed in the placentas and by isolation of the agent through bacteriological culture.

Several species of Pasteurella are natural inhabitants of the respiratory mucosa and reproductive tract of mammals and birds (Schlater et al. 1989). Hence, these are the sites most frequently affected by this agent. Generally, these bacteria are opportunistic and cause secondary infections or after-stress situations (Schlater 1989). According to the veterinarians responsible for the cases, the mares in this report did not show any clinical signs or history in the days before or after abortion that could be associated with any pathological or stressful condition. The relative immunosuppression during pregnancy may have been the contributing factor to the colonization and consequent infection by $P$. pneumotropica in the placenta. Thus, in both cases, the abortion may have been the result of a primary infection, since no other pathogen was isolated from the fetuses or placentas.

As for the source and route of infection, the analysis of the histological lesion distribution concentrated in the placenta associated with bacterial isolation in Fetus 2 showed an ascending route of infection. Despite presenting lesions similar to placentitis caused by Rhodococcus equi, in abortions caused by this agent, the inflammation occurs around the blood vessels and interstitium, and is mainly composed of macrophages and, in smaller quantities, lymphocytes and neutrophils, suggesting a hematogenous route of infection in these cases (Patterson-Kane et al. 2002). The isolation of $P$. pneumotropica from the lung and stomach contents of Fetus 1 may be explained by the aspiration and swallowing of amniotic fluid by the fetus since no histological changes were visualized in these organs. Although there were different macroscopic changes in the placenta of the two cases, the histological lesions characteristic of bacterial infectious processes were associated with myriad bacteria, which corroborates the results of Whitwell (1988), who reported the importance of histological analysis associated with complementary tests in the evaluation of the placenta, since placentitis can have different degrees of severity that are not microscopically evident. 

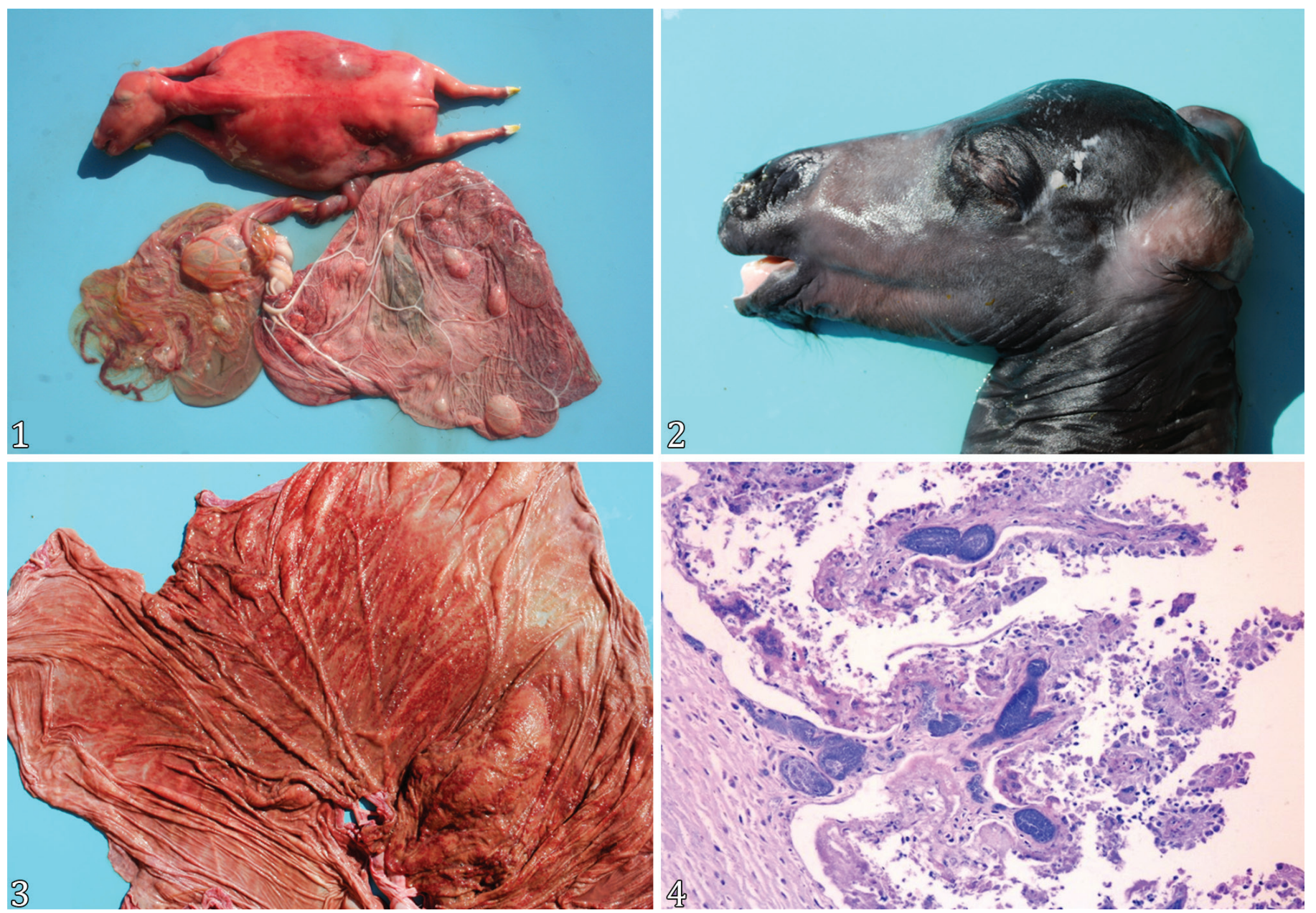

Fig.1-4. Equine abortion associated with placentitis due to Pasteurella pneumotropica. (1) Fetus 1 with anasarca and petechiae distributed throughout the skin; moderately hyperemic placenta. (2) Fetus 2 with multiple irregularly contoured, slightly elevated white plaques on the skin, randomly distributed over the head. There is whitish mucous secretion in the nostrils. (3) Placenta that is thickened and markedly reddened (Fetus 2), especially in the microvillus areas. (4) Photomicroscopy of the placenta (Fetus 1). Chorionic villi with moderate suppurative inflammatory infiltrate associated with multiple basophilic coccoid bacterial myriads. HE, obj.40×.

The etiologic agents commonly found in cases of bacterial placentitis responsible for abortion in horses are Streptococcus equi subsp. zooepidemicus and Escherichia coli (Whitwell 1988, Hong et al. 1993, Smith et al. 2003). Hong et al. (1993) described cases of abortions and stillbirths in horses and reported Pseudomonas aeruginosa, Klebsiella pneumoniae, Actinobacillus spp., Staphylococcus spp., Leptospira spp., and Nocardioform actinomycetes as causative agents. However, there are few reports of opportunistic bacteria associated with abortions secondary to placentitis. Cases of necrotizing placentitis by Encephalitozoon cuniculi (Patterson-Kane et al. 2003, Szeredi et al. 2007), placentitis and fetal bronchopneumonia by Dermatophilus congolensis (Sebastian et al. 2008), and pyogranulomatous placentitis and fetal pneumonia by Rhodococcus equi (Patterson-Kane et al. 2002) have also been described. A report of $P$. pneumotropica as the primary agent causing abortions in equine species is very important as this bacterium, in addition to being potentially zoonotic, may be involved in unexplained cases of mortality, including embryonic mortality.

\section{CONCLUSION}

Pasteurella pneumotropica may be the primary causative agent of placentitis and abortion in horses and should be considered a differential diagnosis in gestational losses in this species.

Conflict of interest statement.- The authors declare that they have no competing interest.

\section{REFERENCES}

Franciolli A.L.R., Cordeiro B.M., Fonseca E.T., Rodrigues M.N., Sarmento C.A.P., Ambrosio C.E., Carvalho A.F., Miglino M.A. \& Silva L.A. 2011. Characterisitics of the equine embryo and fetus from days 15 to 107 pregnancy. Theriogenology 76(5):819-832. <https://dx.doi.org/10.1016/j.theriogenology.2011.04.014>

Ginther O.J. 1992. Reproductive Biology of the Mare: basic and applied aspects. 2nd ed. Equiservices, Cross-plains, WI.

Hong C.B., Donahue J.M., Giles R.C., Petrites-Murphy M.B., Poonacha K.B., Roberts A.W., Smith B.J., Tramontin R.R., Tuttle P.A. \& Swerczek T.W. 1993. Equine abortion and stillbirth in central Kentucky during 1988 and 1989 foaling seasons. J. Vet. Diagn. Invest. 5(4):560-566. <https://dx.doi. org/10.1177/104063879300500410><PMid:8286455> 
Mannheim W. 1984. Family III. Pasteurellaceae Pohl 198la, 382, p.550-552. In: Krieg N. (Ed.), Bergey's Manual of Systematic Bacteriology. Vol.1. Williams and Wilkins, Baltimore, MD.

Miller D.A., Wilson M.A. \& Kirkbride C.A. 1989. Evaluation of multivalent Leptospira fluorescent antibody conjugates for general diagnostic use. J. Vet. Diagn. Invest. 1(2):146-149. <https://dx.doi.org/10.1177/104063878900100210> $<$ PMid:2488332>

Miller R.M. \& Dresher L.K. 1981. Equine ulcerative lymphangitis caused by Pasteurella hemolytica. Vet. Med. 76(9):1335-1338. <PMid:6916557>

Minton E.J. 1990. Pasteurella pneumotropica: meningitis following a dog bite. Postgrad. Med. J. 66(772):125-126. <https://dx.doi.org/10.1136/ pgmj.66.772.125><PMid:2349182>

Nimri L.F., Rawashdeh M. \& Meqdam M.M. 2001. Bacteremia in children: etiologic agents, focal sites, and risk factors. J. Trop. Pediatr. 47(6):356360. <https://dx.doi.org/10.1093/tropej/47.6.356><PMid:11827304>

Patterson-Kane J., Donahue M. \& Harrison L.R. 2002 Placentitis, fetal pneumonia, and abortion due to Rhodococcus equi infection in a Thoroughbred. J. Vet. Diagn. Invest. 14(2):157-159. <https://dx.doi. org/10.1177/104063870201400211><PMid:11939338>

Patterson-Kane J.C., Caplazi P., Rurangirwa F., Tramontin R.R. \& Wolfsdorf K. 2003 Encephalito zooncuniculi placentitis and abortion in a Quarterhorse mare. J. Vet. Diagn. Invest. 15(1):57-59. <https://dx.doi. org/10.1177/104063870301500113><PMid:12580298>

Saxegaard F. \& Svenkerud. R. 1974. Pasteurella haemolytica associated with pneumonia in a foal. A case report. Acta. Vet. Scand. 15(3):439-441. <https://dx.doi.org/10.1186/BF03547470><PMid:4414992>
Schlater L.K., Brenner D.J., Steigerwalt A.G., Moss C.W., Lambert M.A. \& Packer R.A. 1989. Pasteurella caballi, a new species from equine clinical specimens. J. Clin. Microbiol. 27(10):2169-2174. <https://dx.doi.org/10.1128/ jcm.27.10.2169-2174.1989><PMid:2584369>

Schlater L.R.K. 1989. Anaerogenic Pasteurella-like organism isolated from horses. J. Vet. Diagn. Invest. 1(1):3-5. <https://dx.doi.org/10.1177/104063878900100103> <PMid:2488648>

Sebastian M.M., Giles R.C., Donahue J.M., Sells S.F., Fallon L. \& Vickers M.L. 2008. Dermatophilus congolensis-associated placentitis, funisitis and abortionin a horse. Transbound. Emerg. Dis. 55(3/4):183-185. <https:// dx.doi.org/10.1111/j.1865-1682.2007.00981.x><PMid:18405341>

Smith K.C., Blunden A.S., Whitwell K.E., Dunn K.A. \& Wales A.D. 2003. A survey of equine bortion, stillbirthand neonatal death in the UK from 1988 to 1997. Equine Vet. J. 35(5):496-501. <https://dx.doi. org/10.2746/042516403775600578><PMid:12875329>

Szeredi L., Pospischil A., Dencsö L., Mathis A. \& Dobos-Kovács M. 2007. Acase of equine abortion caused by Encephalitozoon sp. Acta Vet. Hung. 55(4):525532. <https://dx.doi.org/10.1556/AVet.55.2007.4.11><PMid:18277711>

Ward C.L., Wood J.L.N., Houghton S.B., Mumford J.A. \& Chanter N. 1998. Actinobacillus and Pasteurella species isolated from horses with lower airway disease. Vet. Rec. 143(10):277-279. <https://dx.doi.org/10.1136/ vr.143.10.277> <PMid:9787421>

Webb R.F., Cockram F.A. \& Bryden D.I. 1980. The isolation of Pasteurella haemolytica from an equine foetus. Aust. Vet. J. 56:610.

Whitwell K.E. 1988. Proceedings of the 5th International Convention on Equine Infectious Disease, University Press, Kentucky, p.172-180. 